University of Louisville

ThinkIR: The University of Louisville's Institutional Repository

Electronic Theses and Dissertations

$5-1922$

\title{
Woman's place in modern drama.
}

Ruth Wilson

University of Louisville

Follow this and additional works at: https://ir.library.louisville.edu/etd

\section{Recommended Citation}

Wilson, Ruth, "Woman's place in modern drama." (1922). Electronic Theses and Dissertations. Paper 1583. https://doi.org/10.18297/etd/1583

This Master's Thesis is brought to you for free and open access by ThinkIR: The University of Louisville's Institutional Repository. It has been accepted for inclusion in Electronic Theses and Dissertations by an authorized administrator of ThinkIR: The University of Louisville's Institutional Repository. This title appears here courtesy of the author, who has retained all other copyrights. For more information, please contact thinkir@louisville.edu. 


\title{
UNIVERSITY of LOUISVILLE
}

* * * touar's PLAce In MOdERN dRaMa * * *

\author{
A Dissertation \\ Submitted to the Faculty \\ Of the Graduate School of Arts and Sciences \\ In Partial Iulfiliment of the
Requirements for the Degree
of
Yaster of Arts

Department of Fingliah

By

Ruth Wilson

1922 


\section{TABLE OF CONTENTS}

13198 
TABLE OF CONTENTS

- ***-

Introduction.................. Page 1-14

CHAPTER I.

Women in the Home............... Page 14-23

CHAPTER II.

Fayward Fomen.................. Page 25-89

CHAPTER III.

The Eternal Triangle............. Page 40.52

CHAPTER 2V.

Women and Commercialism............ Page 53-65

$-* * * * *-$

Conolustorie..................... Page 66-69

Plays used in Thesis.............. Page 71-72

Bibliography•................. Page 73-74 


\section{INTRODUCTION}

Wile the character of women in the plays of anciant times has ever played an important part in the history of the drama, the appearance of women in the feminine roles is a distinctly reoent development. It might woll be said that this is a fairly modern addition to the stage. Perhaps if Aeschylus or Shakespeare were here to-day, they would shake their heads and sigh because women, whose place they considered to be in the home, should have so far degraded themselves as to appear before an audience on an equal footing with their husbands or brothers. They would probably never realize how much better would have been a woman's interpretation of a woman's part. This advance of women then into the public eye would be no less preposterous to them than the idea of women in polities was to our own mon folk a fow years ago.

In order to lead up to the time when women first appeared on the stage, it might be well to consider woman's position in the early drama, and to give a brief sketch of the history of the drama in the various countries.

The inhabitants of India belonged to the Aryan race. These peoples settled dow, after their migrations to three different peninsulars, and advanced three distinct oivilizations. one 
branch made its home in the Hindu peninsular and spoke the sanskrit tongue; the second went to the Italian peninsular and spoke the Italian language; while the third great group of this Aryen family settled in the Orecian peninsular and spoke the Greek language.

This last division became the most cultured of a11. The Greoks not only gave to the world the aesthetio and intellectual qualities which dominate the cultured peoples of to-day, but they originated the drama---the most powerful factor in modern life and oducational development.

In ancient Greece wo see the savage people assembled on occasions on the village green to celebrate the great god Dionysus, the personification of nature's great productive force. The peasants seleoted a level ploce on the side of a hill and entertained the gods by means of song and dance. Now and then some votary would spring upon the sacrificial table and relate in glowing terms his personal experiences with the gods. This man, overwhelmed with his great desire to explain to others the adventures of the gods, was the first actor. This sacrificial table, spread by the wizards and soothsayers, was the first stage.

At first there was only one actor, this inspired rotary. At the time of Aeschylus the number of actors had increased to two, and during Sophocles' day there were as many as three. 
As time went on the actors began to dress the part. Thus arose the first costume. Dignified costumes were used for the tragedies and grotesque ones for comedies. The soene developed in as casual a way as did the costume. It was inconvenient, naturally, for an actor to run across the green to a tent and change his garb, so the table, or stage, was placed against the tent. This tent formed the first background or scene, and became the parent of those artistic creations which our popular scenic artists of to-day devise to give color and atmosphere to the modern drama.

This celebration, therefore, grew into our first real dramatic production. There gradually developed along two distinctly different lines the tragedy and the comedy. An intermediate development, more tragic than comic, but given to relieve the tension of the audience, also grew up, which was called the satyr drama.

It is not my desire to take up in detail the development of the drama, but merely to give a skeleton of that development on which to hang the moat of the plays and to show that from the. beginning women were not considered as suitable for work on the stage.

The roles of women in the early Greek drama were taken by young boys whose roices had not taken on the deep masculine tones sufficient to enable them to play the male parts. It is not particularly ludicrous for us to imagine that the young and 
beautiful maidens who played the parts of the sea nymphs, dancing as they did in and about the crags where Prometheus lay bound to the rock in Prometheus Bound, were not girls at all but young boys. It is not ludierous because the Greek boy of that time was as lithe and graoeful as out door life, Olympic games, and dances oould make him. He was equally as nimble as his fair sister in his morements.

In the early times when the Indian peoples still possessed the virile qualities of their ancestors, there arose the nucleus of the great Indian epie poem, Maha-Barata, or the wars of the Barata, which closely resembled Homer's Iliad. Perhaps Homerhimself had come in contact with the pooples of ancient India. At any rate the women characters in this great Indian epic were given a prominent place. The character of Drupadi, the daughter of Panchala and wife of Ayuna, and the character of Pritha, the mother, were perhaps the first women definitely defined in a poem of this type.

From the first book of the Maha-Barata, Kalidasa the great Indian playwright, took his theme of his drama Shakuntala.

In criticising the work of the great Indian playwright, of whom so little is known, we must remember that our tastes, ideals and standards of morality are extremely different from those of early India. 
Kalidasa, Iike Sophoales and Aeschylus, was the author of seven writings, of which one is a oulogy, threo are epics, and three, dramas. The greatest of his dramatic works is Shakuntala. This play is filled with natural beauty and human emotions. It is interesting to note in connection with the title of this thesis that the leading character of the earliest Indian drama was a woman. Taking into consideration the difference in morals, we find the character of slakuntala amazingly modern. She is a girl who loves a man above her in social position, just as any modern girl might do. To him she gives all, believing that she is to be married to him. He forgets her. It is the age old plot which modern dramatists have brought down to modern times and which we are prone to think of as a strictly modern theme.

Critics differ as to whether or not the part of the beautiful daughter of the hermitage was originally played by a woman. If the role was portrajed by a female, it is the one exception to the general rule that women did not appear on the early stage. The passage in Act 111 where the King makes love to Shakuntala is exquisitely poetic and beautiful in its romantic sentiment. It is more satisfying for us to believe with those crities who say that a woman played the woman's part. For instanoe, it is more natural for us to imagine that the King speaks the following 1 ines to a woman 
instead of to some untemperamental boy in his tteens:

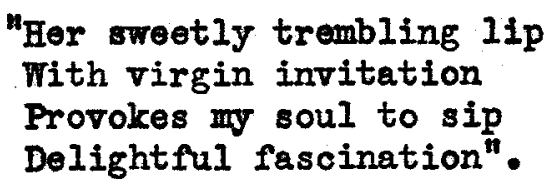

And again:

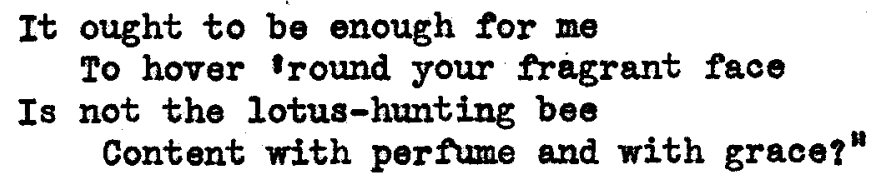

From the branch of the Aryan family which settled in the Italian peninsular, no read dramas were developed in ancient times. The character of women, hóever, was distinctly prominent in the great epic poems. Take for instance the Queen of Carthage in Virgil's Aeneid. Again we see a woman loved and giving her 10ve. When she is left by Aeneis in a moment of woakness, she kills herself.

With the later development of the drama in the Blizabethean period in England, we find that about fifty percent of Shakespeare's leading characters are women. We must not lose sight of the fact that women were never cast for the female parts on the Elizabethean stage. It is interesting to note in this connection that a great many of Shakespeareis heroines possess masculine qualities. For this reason it does not require such a great stretch of the imagination to realize that boys played women's parts.

Katherine, that head-strong shrew whom shakespeare has made so acidly insistant in her demands, can easily be thought of as having been played by a man. Viola and Rosalind both appear 
in masculine garb during the plays. For this reason it is not out of place to consider a boy in girls' costume, if we can also consider a girl in boy's clothing. Even Portia disguises herself to carry out her plans more successfully. on the other hand it is more difficult to adjust our view point to the realization that sweet-souled Cordelia, and the womanly Ophelia were portrayed by males. It is almost impossible for us to picture a boy leaning over the balcony to whisper to Romeon another male, the lines which Shakespeare has put into the mouth of Juliet:

"Thou knowest the mask of night is on my face Else would a maiden blush beprint my cheek For that which thou hast heard me speak to-night."

The early dramatists from the beginning realized the importance of the introduction of female characters into their dramas. How much more accurate would have been the interpretation of these feminine roles had women been allowed to act on the ancient stage. It has remained for the comparatively recent development of the stage to bring out the hidden beauties in the ancient dramas by the introduction of women in women's parts. Let us then take a glimpse at the works of the various playwrights who eharacterized in the various countries, the development of the drama during that period which intervened between the time of Skakespeare and the beginning of the modern era.

The derelopment of woman's place, both on the stage and in the plays themselves, was a gradual one. Just as women developed 
and broadened in her social position and her life in general, just so did she develop in the drama. It was a slow process but a sure one.

We can trace French itterature no further back than the eleventh century and the expression of a language in that country can be found only as early as the ninth century. Evidence, however, of street exhibitions, which were similar to certain forms of the drama were found in Paris long before either the literature of the language had been developed.

The period of the Renaissance was characterized by Jodelle and Garnier who wrote rather primitive types of classical French tragedy.

The dominant power on the stage down to about the middlo of the fourth decade of the setenteenth century was Hardy whose most celebrated play, Yarianime dates from 1610.

Corneille, Pierre Corneille, who was Franceis greatest tragic poet and dramatist did not make his epochal production of The Cid until 1631. The play deals with the marriage of chimene to a man who has killed her father in an honorable duel. In the space of a day she rises to the full consciousness of her attachment to Rodrigue; discovers that he has shed her father's blood; passionately exhorts the king to punich him with death; and then accepts his hand in marriage.

Corneille's Le Menteur, which stands in much the same 
relation to French Comedy as does Le Cid to the progress of French Tragedy, was not produced until 1642.

In the meantime, Raceine, although thirty years younger than Corneille, gave promise of rivaling the dramatist as a writer of tragic plays. His Les Padideurz, (the suitors) is a satirical comedy filled with refined saraasm and clever sketches of character. His heroes as a rule are noted for their gracious glory and his heroines for the pleasing variety of their affections.

In England Dryden characterizes the period between the restoration and the opening of the eighteenth century. In his The Duke of Guise he applied the doubtful parallel of the Catholic league to the recent memories of puritan ancestors. The Jild Gallant was an extravagent and coarse comedy. The Rival Ladies passed from comedy into tragi-comedy. The play is written in rhymed verse and takes up the story of two ladies who disguise themselres as..... pages in order to take service with a gallant whose affections-are set on another.

The Conquest of Granada, may be justly described, it is said, as the heroic play par-excellence as it exhibits Bryden as exultantly carrying through a prolonged effort such as only the splendid vigor of this peruliar genius could have sustained. The coloring of the whole is gorgeous, and the here, Mlanzor, combines in Dryden's own way, the imposing features of the Achilles 
of the Iliad, Tasso's Renaldo, and Artaban of La Calprend Cleopatre. Drydents All for Love is an original and free trettment of Antony and cleopatra.

By the year 1700 Dryden was dead, as was Congreve, one of the most brilliant comic dramatists of the day. The dramatists of this time had reflected the influence of French classical drama and dramatic theory. Raoine and corneille had also been adapted for the English stage.

The Careless Fusband by Cibber, preserved the stock characters of the restoration comedy, purged, however, of their gross excesses but not wholly chastened in spirit. The tendencies of the earlier comedies are maintained in the dramatic works of Urs. Cantlivre. Her characters often have the traits which are easily within the grasp of the actor while the very best of they are pore vital comic creations, She wrote The Wonder A Woman Keeps a Secret whose Don Felix was one of David Garrick's most popular roles.

Lillots yarina is based on Pericles, Prince of Tyre, and gives marked ovidence of his indebtedness to shakespeare. The Fatal curiosity is a domettio tragedy written in three acts of blank verse

While the sentimental drama was to reach its height in Hugh'KeIly and cumberlend, there is in Colman's The Jealous Wife some foreshadowing of sheridan's comic masterpieces. Besides this it is conspicuous as an example of a successful dramatization 
of a popular novel. Mr. and Urs. Oakly, Lady Freelove, and Harriot are a.ll original character portrayals. With the aid of David Garrick he wrote genuine comedy, The clandestine Yarriage. There is perhaps in the illiterate Mrs. Heidelberg the original of Mrs. Malaprop.

The last forty years of the eighteenth century produced few English plays of primary importance. Yot this is an interesting period to consider. Some attributed the deoay of the drama to the rise of the actor. Goldsmith's She Stoops to Conquer was not original in plot but the characters are dram from life and are touched, as it were, by Goldsmith's indescribable charm.

Sheridan's The Rivals gave to the dramatic library a comedy of incident, and incidentally, Iydia Ianguish. The School for scandal was the last great Fnglish comedy. Sir Peter Teazle and Lady Teazle are examples of what an overcivilized society develops. Sheridan has put on the stage the psychology of the overestimated world of fashion. Lady Teazle was first played by Mrs. Abington who with Urs. Clive, did much to elevate the stage and assert women's place on the stage and her right as an actress of ability.

In Germany the outstanding figures are schiller and Goethe. In the Bride of Yessina Schiller has arranged a new version of the eternal triangle. The story deals with the enmity existing between two brothers growing out of the fact that they are in love with the same girl--B eatrice. The woman, without kmowing 1 t, is the sister of her two lovers, Don Caesar and Don Manuel. There is a marked 
contrast between the two brothers. Don Caesar is hasty and wrathful--Don Manuel melancholy and reserved.

In the nineteenth century Goethe was the central

figure of that classical group which gathered around the court circle at Foimar. His Faust is immortal and has been listed along With the Hebrew Bible, Milton's Paradise Lost, Dante's Divine Comedy and Shakespeare's works. These together with the Greek classical poems and epies may justly be called the literary bibles of the human race.

The character of Gretchen, or as it is later known, Marguerite, possesses a charm of imocence which clings to her in spite of her guilt. Herein, the poet, shows his wonderful skill, for he does not try to veil or excuse her offenses and yet he fills us with that love of the heroine which purity alone can inspire.

It has been arnest aim in this introduction to give a brief sketch of the origin and development of the drama and to show woman's grádual settling into a place of prominence in it, as shown by the literature of the countries where drama has played an important part in the advance of cultural civilization.

In the following chapters it shall be my purpose to advance some of the most difficult problems which have confronted woman and have affected her place in the drama, and to show how important woman has always been in the solution of de those problems. 
Chapter 1.

WOMEN IN THE HOME. 
Chapter 1.

WOMEN IN THE HOME

The prevalent idea has ever been that woman's place is in the home. It is only recently that she has been considered has having any definite influence outside her so called natural realm.

It has been the interesting and appreciative duty of the novelists and dramatists to show the public that women must be free from the conventional conception of her rights and duties oven if this means leaving her children, husband, home and fireside. It has taken Henrik Ibsen to sound the trumpet call of woman's freedom.

His three most widely read plays, Ghosts, Hebba Gabler and $A$ Dollis House, deal with the problem of the home and the false ideals of marriage which men have erected to govern thetr conduct. He has attempted three distinctly unsatisfactory solutions of the problem. He shows us that no tyranny is greater than the despotism of a false ideal. With this idea in view, he attempts, in these three plays, to show us where these tottering standards lead men, and more truthfully, women.

A Doll's House tells of the struggle of Hora Helmer against the influence of her invironment, her heredity, and the social con- 
ventions which retard her development as an individual and as a human being. Ibsen, speaking through Hora Helmer, would have us all delivered from these false conoeptions and ideals. His message to the rorld and to all mankind is to be freel Wo mast be free, even if that freedom means shooking the easily-shocked public. Hora observes that it is the mon who make the laws, and that contemporary society means a sooiety for men; not a society for human beings.

From the beginning through the middle of the third act, the story is not much more than an ingeniously invented tale, frivolous, light and airy, with little to suggest the tragedy that is to come.

Iora is the petted, spoiled doll-wife of Torvald Helmer. She is simple and child-like with 11ttle knowledge of the outside world to mar the perfectness of her domestic life. We find her absorbed in her home and hor children, giving little thought to the way in which her husband keeps her in money. But on the other hand this ignoranoe is not entirely her own fault. Torvald is the exact opposite in nature to his wife. He shields her from the petty cares that infest his work-a-day world; protects her from the things he feels she should not know but which she would have profited by had she perceived them; in short--me makes 2 doll of her. He does not give her credit for common sense enough to be his pal and a partmer in his married 1ife. At the time when she needed his love and protection, he, with righteous indignation and bruised pride, condewns her for that for which he is the direct cause. 
Helner professes his love for his wife on many occasions. He declares his devotion to her in these words: "Yora, I often wish I might risk body and soul, and overything, everything for your dear sake." There is not doubt that Helmer loves his wife with that narrow selfish lore that will not stand the braoder tests of time. How shallow those words must have seemed to the chlld-wife when she puts her hasband to the test! What a hollow mockery his professions of love must have been to her when she realizes that he is speaking to her in these lines: "I would gladly work for you day and night, bear sorrow and want for your sake, but no man sacrifioes his honor, even for the one he loves". Her reply is:- "Millions of women have done so."

Nora is amakened. She realizes that everyone "shares the responsiblifty and guilt of the society to which he or she belongs." Her spiritual development springs from the firinconvietion that she can become responsible for the welfare of the children only by gaining responsibility for herself and by acquirIng a knowledge of society through contact with the great world outside. She knows little beyond the narrow confines of her doll-house for she has been rigidly shielded from contact with 211 that is sordid and natural. This responsibility, however, can never be gained by remaining in the home. Hora makes her own devision. We get the gist of the play from her conversation with her husband in the last act. The tone of the play changes 
and a deeper note is struck for the first time when husband and wife settle down to disouss their relations to one another. This is the first time they have seriously. considered their selves in comparision with their mate.

one might be justified in considering that Nora would feel her duty to her ohildren as a sacred responsibility. We must remember at the same time that Helmor has so led Hora to believe she is not a fit companion for her children, that she felt she would be doing them an injustice by contaminating them with her loathsome presence. Society may hold up its hands in horror because Nora abandoned her children rather than surrender her individuality, submerge her true nature, and crueh her desire to prove a useful member of home and society, but Ibsen feels that by leaving home, she has arrived at the only probable solution to her great problem. He does not believe that a woman must give up her individuality and personality because of the narrowness of the conventions.

In speaking of Krogstad, Helmer voices his contempt for one who sins as Hora herself has sinned, in the following lines: "Such a dust cloud lies poison and contaminates the whole air of home. Every breath the children draw contains some germ of evil." And later:-

"Hearly all cases of early corruption may be traced to lying mothers." Hora realizes that it gives her husband a positive sense of physical discomfort to come in contact with 
poople like herself. There is only pity in our hearts for the girl who grew to womanhood to face, all unprepared, the momentous problems of the home. Hora, the light-hearted, is turned into an understanding woman who breaks with the institutions of marriage when she finds that she is not fitted to be the mother of her own children. Yarriage and free-selfdevelopment cannot go hand in hand.

Iraturally an audience mants to see the characters in whom it has become vitally interested, happy. But if to bring about this happiness, truth to human nature and the death of self-development must be sacrificed on the alter of marriage, then the characters must not be happy. Imagine, if you can, Ibsen bringing Nora back from the door in the last act, and casting her into the forgiving arms of hor husband. Wo. The play would fall flat if it did not leave to our imaginations and out oternal curiosity, the means by which Nora worked out her problems and extricated herself from her difficulties.

$$
\text { Ghosts is a catastrophe play. Softening of the }
$$
brain as the result of a disease from a licontious father is a subject repulsive enough to excite the morbid interest of an audience. It is even more sordid when we consider that it is used as the chief characterisitio dominent in one of the leading characters of a very popular play.

When the curtain rises on the first act, everything 
except the inevitable has taken place. Ilsen has a way of concerning himself only in the end of the play, in the working out of the problem, not in the presentation of the causes of the problem. The cause of the tragedy is over before the play begins. It remains only for the inevitable to happen.

The probien in Ghosts and the question wich Ibsen so tragically and negatively answers is:

"Do the children really benefit by the mother's surrender in living alle in marriagel" The answer is no. In comparing the two plays, the conditions of Hora Helmer and Mrs. Alving are by no means identical. There were no such disastroud consequences prohesied for the children of the morally. upright Helner as fell the lot of the son of the immoral reprobate, Chamberlan Alving.

The play brings out a tremendous demonstration of the power of heredity. The tragie, overpowering, and terrible development of the play is scarcely relieved by lighter touches. The first tragedy appears in Act 1 , when we realize that $\mathrm{Krs}$. Alving 8 sacrifice did not help matters in the least. She could never blot out the horrible stain of the law that "the sins of the father shall. be visited on the children." Mrs. Alving's whole life is hypooritical, growing out of a loveless marriage. As a result of deception the home life of the Alvings is one lie after another. Mrs. Alving tries cainly to sook happiness in duty done, but happiness is not to be her lot. She must pay the penalty--that is Ibsen's way of 
teaching a lesson. There is sympathy in our hearts for the mother whose son rebukes her:-

"I never asked you for 1ife. And what kind of a life was it you gave me? I don't want it You shall take it back."

In $A$ Doll's House Hora leaves as a solution to the problem that faced her in her home. In Ghosts Urs. Alving remains as an attempted solution to her problem.

In Hodda Gabler Ibsen has given us a psychological portrait of Hedda, a woman out of harmony with her surroundings. The problem in this case is pure incompatibility and could never have been worked out. The only possible solution is after all, not a solution: Hedda should never have come into the home.

In rogard to The Unchastened Toman, by Louis $\mathrm{K}$. Anspacher, it has been said that Caroline Knollys, the wife of Hubert Knollys, is perhaps Mr. Anspaoher's idea of what Hedda Gabler would be lire if Hedda had lived in East sixty-sixth street, Hew York City. Like Clyde Fitch, Anspacher picks his heroines from the idle and frivolous ranks of urban society and makes her his chief concern. This play might more aptly be classed under the division of this thesis lnown as The Eternal Triangle, but because of the resemblance of Caroline to Hedda, it may also be considered here. The problem arises when Caroline whom the dramatist has endowed with a kind of pepetual youth, a purring charm, dominent will and pretty wit, combined with the manners of the luxury loving class, attempts to win another man away from his wife. Her main idea seems to be to play as close to the flame as she can without scorching her wings, 
The ides of the play is the attempted stuity of

a woman who is inoapable of being a true normal wife because of her essentially selfish and trivial nature. Yet caroline is not wholly bad. If she were entirely corrupt and had some definite reason for her corruption, we might forgive her. As it is, she is as incapable of being an ultimately unfaithful wife as she is of being a true one. Perhaps this is due to the lack of real passion in her, and because she fears the consequences of breaking the laws of conventions. In this respect Caroline resembles rather closely Ibsen's Hedda. Hedda is entirely deficient in moral scruples, nevertheless she dreads a scandal. Outwardly she remains faithful to her young husband; inwardly she is an audulteress. In thought she can sin; in deed she dare not: Caroline had previously caught her husband in an act of unfaithrulness and she uses this knowledge as a whip orer him. The victim of her own desires is one Lawrence Sanbury, an architeot. His wife stands out in marked contrast to Caroline. She is active and energetio, and idealistic. The two women urge Lawrence to follow two distinctly different ways in attaining success. Caroline urges him to cater to the rich; his wife insists that he push forward by being uncompromisingly himself and by bringing out the qualities which are inherent within him. It is not until Hubert is able to get a whip over caroline by discovering that she has gone too far with Iarrence, and that the knowledge of her indiscretion might ruin her social position, that caroline is brought to her senses and made to 
realize that she is not only wrecking her happiness and the happiness of two homes. Caroline is foroed to apologize publically. Anspacher thinks this is the only means of humiliating her. And yet she is allowed to make her final exit with a smilestill unchastened. She isn't regenerated. She is never sympathetic. And unlike Hedda, she isn't even tragic.

Home, it seems to the dramatist, is what the women choose to make it. The problem is one of all time, and its possible solutions are deterimined not $s 0$ much by the atmosphere in which the characters move and have their being, but more often in the possibilities of reform which are in the women themselves. In concluding this chapter let me reiterate: Woman's place was originally in the home. It is natural, therefore, that the dramatist in considering wowen as a vital being to be reckoned with, should consider her first in her natural environment, as an important $\operatorname{cog}$ in the wheel of family life.

The drama as the most social of the arts, teaches us much that we already know. "Fanily studies in the theatre", says Chandler in Aspects of the Yodern Drama, "Afford no novel idea yet they display with moving force the world of human character in which we live." If these problems of the home interest us at all, it is by making us feel.

In most of these problems of the home the aim is purely pictorial---the presentation of persons closely allied by blood or marriage, whose peculiarities are thrown into prominence by some 
family orisis. For the most part the orisis is less important than the characters wich it affeots.

It has been my aim in this chapter to show that modern dramatists considered women as a vital olement in fomily 1ife, and in the solution of the problems wich make up daily life in the average family, they have woven interesting plots that like the strong warp or the weak woof produce a fabric, fascinating, but not alvays durablo. 
Chapter II.

WAYWARD WOMEN 
Chapter 11.

\section{TATHARD WOMEN}

\section{Nomen with a Present.}

2. Tomon with a Past.

It has beon said that there is no such thing as

an immoral subject for a play; in the treatment of the subject, and only in the treatment, lies the basis for othical judgment of the piece. It is by no means the business of the dramatist to formulate the laws of conduct, to say what is right and what is wrong, to judge the rules of behavior of the characters in general. This is left to the social scientist, the ethical philosopher, and the religious teacher.

The business of the dramatist, then, is not to formulate laws, but merely to tell the truth about centain specific characters which he has drawn for our consideration, and to show us how they would aot under certain specific situations.

Dramatists have coneerned thomselves to a large extent, in the last 'twenty years particularly, with the modern problem play. These plays are the launching of an individual point of view; a sort of self-conscious criticism of life. The dramatists have taken upon themselves the job of attempting to work out the complexity and reality of life, or as it has beon appropriately 
put. "to get beneath the surface play and pageantry of life; to use life materials as the basis or life meanings".

The ohief characteristies of the problem play are a sense that life is real and art ought to be vital, and that life is exoeedingly complex.

The wayward woman, the one who strays either by her own volition or some outside influence from the straight and narrow path of organized society, seoms to have come in for more than her share of condemnation and criticism. Nost of the problem plays center around the character of some woman who has sinned in the past, or who has an immoral present. Now and then in the working out of the plot there is the suggestion that she will also have an immoral future. Sometimes the dramatist chooses to make her wayward through the offeot of her anvironment, and very seldom through luet or passion.

The problem plays which oenter around the orring sister do not do as much harm as one would naturally expect. Perhaps this is due to the fact that liventiousness and vice are not painted in glowing colors, they are not made attractive, and the men in most cases are more to be condemned then the women. This is particularly true of the men in Maeterlincle's Yonna Vanna, and Eugene Nalter's The Basiest Try.

Let us then consider Maeterlinck for a few moments. His subtle tought finds expression in plays of justice, fate, and human destiny. He pictures strange men and women; characters we seldom 
meet in the course of the day. These men and women lack something of the naturalness and healthy vigor of flesh and blood heroes and heroines. They seem to be delicately tuned to the throbbing rythm of 1ife. How and then they get out of harmony with their surroundings, and it is under the stress of conditions that they make the play interesting. His men and women seem spurred on by some fate; they pulsate by means of intuitions and premonitions. It is this pulsating that makes his women different and therefore worth our grave consideration.

Yonne Vanna was written in 1902 and was unusually successful in every country where it was presented except in England where the censors fordid its presentation on the English stage. Lonna Vanna herself, is a typical example of a woman who is driven to wrong doing by a selfish and narrow-minded husband. The problem of the play can best be stated by the two questions which the dramatist answers in the affirmative, Can a woman be physically dishonest and yet be spiritually pure, and should a woman sacrifice her honor for her country or for the welfare of others as boldly as she would sacrifice her life? In the process of answering these questions, Yaeterlinck has woren a great play.

He shows us two points of view. There is the confliot between the substantial but somewhat clumsy conventional point of view of Cuido, and the spiritual uplifting one of Vanna. 
Yonne Vanne is a woman who stands out head and shoulders above the average woman character on the modern American stage. She is a full length portrait painted by a master artist for the world to gaze upon. to love, to pity and to admire. There are two struggles existing in the drama, the struggle between love and duty, and fuido's struggle between love and the truth---the truth that must be reasonable. The plot, the background, and the other characters are merely there to offset the character of Monna Vanna.

"Browning" says Phelps, "tells us that even a crime may be a test of virtue". Monna Vanna's decision was surely a test of her husband's love and faithfulness. Arthur symons speaks of Yonna Vanna in these words, "Here is a play in which almost every charecter is noble, in which treachery becomes more vital than truth, and only what wo are accustomed to call virtue, shows itself mean and even criminal. And it is most like life as life really is in this, that at eny moment the whole course of action might be changed, the positions of every character altered or even reversed by a mere decision of the will open to each---that the choice could be otherwise."

Yonna Vanna is high-idealed and self-sacrificing. She decides against her husband's will, to go to the camp of the enemy and give her life (if need be) for the people who cry pitiously for bread without the palace gates. 
Guido loves his wife with a selfish sort of love, he is no stronger than his love. Vanna, on the other hand, is big in heart and purpose, and is willing to undergo any danger to save her starving people. Then Vanna returns, Guido refuses to believe that "he did not touch" her. Male selfishness in its most disgusting form is exhibited in the last act. The utter unreasonableness of man is revealed when Guido who has time and again demanded the truth from Vanna, refuses to accept her answer for the truth. His refusal is based on the fact that he does not believe the action of Prinzivalli towards his wife is reasonable. He realizes that Prinzivalli's actions are contrary to those of the average man placed in a similar position. Guido is blind, and absolutely incapable of believening in the virtue that is not dictated by convention. As a result he loses his wife through the narrowness and seleishness of his own soul. Vanna tells him, that since he will not accept the truth, then she will tell him what he wants to know. She realizes that Guido has forfeited her love on the alter of unbelieveing.

It must be remembered that Monna Vanna was driven to her action by Guido. She was faithful to him until she saw that petty selfishness had supplanted his love for her. It is not until then that she decides to deceive him to satisfy his vanity and his gross stubbornness. Naturally she is willing to take the consequences.

"Yes, it has been a bad dream---but the beautiful one will begin again. The beautiful one will begin again." 
Vanna deserves a beautiful dream. The dramatist leaves us to imagine the secret meetings of Ianna with Prinzivalli in the underground dungeon. the key to whioh she alone has access. Guido who has brought on his wife's unfaithfulness by his refusal to trust her, also deserves a dream-m-not quite so beautiful. The problem play dramatist realizes that on a happiness platform the problem of convention cannot be solved. There is perhaps a sort of happiness in store for Vanna, an unconventional happiness based on the hope of clandestine meetings with her lover. There is peace for blind Guido who has forced his wife to her decision, but there can be no happiness nor peace for old Marco seeing as he does the falsity of the lives being lived around him, and being by honor bound not to interfere with their natural courses. Is this after all a happy ending?

In Eugene Walter's play The Easiest Way we see a woman with a past who tries vainly to live a perfect present. Because of the selfish and false ideals of the man who professes to love her, and the hand of the man who pulled her down and is every ready to shove her a little farther along the path of least resistence, she is forced to seek the easiest way of living the rest of her immoral life. Her last words to her maid sum up the tragedy of the drama, "Yes I'm going to Rector's to make a hit, and to hell with the rest $\mathbf{l}^{n}$

There can be only pity in our hearts for faura Murdock, the pretty little show girl who has gone west with a stock company 
and falls decently, desperately and honestly in love with John Madison, a peculiar type of wosterner. There is only pity despite the author's condemnation of her. He has attempted to paint her as balck as possible, and only succeods in leaving with us an impression of a pathetic little gray figure against an inky background of conditions and characters. In contrast with the male characters hechas made her a vivid rose color struggling to become snow white but doomed to remain as she is, or even a shade darker, because of the lack of fit companions who may help her clense her sould. Walters has failed to prove the truth of his statement, "her fascination was as undeniable as her insincerity of purpose". Sho is soft-voiced, protty and girlish-more sinned against than sinning. With all her past experiences, tragic and othorwise, Laura Yurdock has found nothing equal to her sudden, swiftly increasing love for the young westerner. on the other hand, John knew that he had awakened in her an honest 10v0, the first real decent affection she has show, and she in turn has and is awakening in him his first desire to be a man in the biggest sense of the word. He wanted to do things worthwhile. to amount to something, to play the game of life fairly, decently out in the open.

If Laura had remined in Denter, the play possibly would have had a happing ending. But John puts her to a test, she is sent to New York alone to lead a atraight life. No find her here later in a cheap boarding house, hungry penniless, and dependent, almost desperate, and haunted by the fear that her lover has forgotten her. 
It is quite easy for her to slip back into her old ways of ease and luxury. On the other hand it must be remembered that fust as we pointed out that Yonna Vanna sinned only when she was driven in desperation to it, Laura takes the easiest way only after her lover and the man to whom she has been misteess, have shown her the other way, and have made it diffioult and unbearable. Will knows the test to which Iaura is to be put. He speaks ber in conversation with John in the first act,

"I hope you'l1 make your money because I tell you frankly that's the only way you can hold this girl. She's full of heroics now, self-sacrifice and all the things that go to make up the third act of a play, but the minute she comes to darn her own stockings, wash out her handkerchiefs and dry them on the window, and send out for a pall of coffee and a sandwich for lunch, take it from me, it will go - bahl You're in Colorado writing letters once a day with no checks in them. That may be allright for one who has not tasted the joy of easy living, full of the good things of life, but one who has been doing very well in the way these women do is not going to let up for any great length of time."

Tho is it, we ask, who gave her the taste of the joy of easy living? Will and Will's kind. Who has taught her to orave the good things of life and has given them to her for the price which she should never have been asked to payt Will, and the rest of the Wills of New York. Can we sit in the seat of the scornful and judge the girl who sinks deeper and deeper into the mire of $\mathrm{sin}$ and degredation 
simply because those woldould have helped her turned a deaf ear and masked their conceit under the nome of high and mighty manhood Cold, unforgiving selfish brute that John is, he lets Iaura's pleadings of love go unanswered. He imagines with all the collosal conceit that he is too good for her. Laure pleads, "I love you, I---how can I tell you, but I do, I do, and you wont believe mel" He answers, "I think you do in as far as you are able; but Laura I guess you don't know what a decent sentiment is. You will sink until you are down to the very bed-rock of depravity. I pity you."

Ies, he pities her. What a poor recompense when one is craving love and protection; when love is the only thing that will save har. How can any beaing that calls himself a man, refuse to listen when Laura pleads with him to let her lean on him. How heartlessly he tells her that she has leaned the wrong way. Iaura's past may have been of her own making, but her immoral future and her present state of living are the work of John and Will. Her wayward future certainly will be caused by the one who pretends and considers himself far above her in ideals and ambitions. He lacks human understanding, and while he may know what a decent sentiment is, he is lacking in even the faintest tinge of altruism and deepseated love.

With infinite grief, we are told by the authot, with resignation and hopelessness, Laura mutters the words, "Oh cod, Oh, py God." as she totters towards her bedpoom. It is left to us to deoide whether Walter accomplished his task--that of teaching a noble moral lesson by exposing some of the sins of society. 
Henry Arthur Jones has depieted for us a voman with a past and a man with an imoral present. I refer to Mioheel and his Iost Angel. Ludite is a frivolous type of woman who takes a great fancy to the rector of the churoh. $s_{\text {he feels the }}$ need of spiritual advice, or is it merely a desire to be near the man she has deoided to lover Her desire of conquest leads Michael to his domfall. The plot of the play revolves around the situation developed when achael finds himself falling into the ways of besetting sin. He realizes that he must mete out to himself the same punishment that he has previously exacted from Rose, the daughter of his confidential seoretary. It would not be fair to Yichael to say that he yielded to the wiles of this wayward moman without stating that he resisted the alluring attraction of Audrio with all his feeble moral strength. The matter with wich we are concerned, and on which the dramatist has made his play, is that he did in time yield to her. In Act II, Michael thus soliloquizes: Why did you come into lifer I did not seek you. Tou oame unbidden, and before I was arrare of it, you had unlocked the hollest places of my heart. Your skirts have swept through all the gatemays of my being. There is a fragrance of you in every cranny of mo. You possess mo. Hol Hol I will not yield to you." Audite then comes to him, and Michael tells her he will do anything in his power for her best, her heavenly welfare. Audrie answers: 
"I dont think I care much for my heavenly welfare

at this moment. You tumbled me off my pinnacle and there I stuck in the mud."

Wile Audrie is perhaps the one to blame in the downfall of Michael, she is to be pitied in that no one ever told her that love was sacred. Michael consoles her with these words:

"Nobody ever does tell us that until we hear it from our own hearts." Michael condems himself and exonorates Audrie from the entire blame of his downfall in these lines:

"No devil has any power over any soul of man until the man first gives him entrance and consent."

There is a marked contrast in Uichael and Helmer of Ibsen's $\triangle$ Doll's House, especially in the attitude of man's sacrifice for the woman he loves. Helmer says that a man will sacrifice overything for the woman he loves except his honor. Audrie in speaking of Yichael's relations to her, says, "It's an arful delight to think that a mon would risk hell for one." She continues, "There arenit many men who would dare lose this world for the woman thay lovenhow many are there that would dare to lose the other."

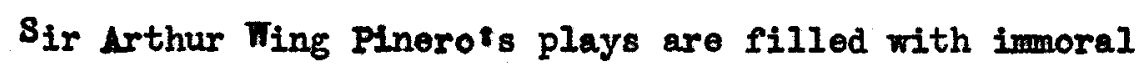

women and imoral types. In The socond Irs. Tanqueray we have Paula as an excellent example of a woman with a past. Paula is reformed and has arried, yet sho learns the hard lesson that socially the women with a past can have no future. The question in the play has been appropriately stated as:

"Can marriage clothe with respectability the woman who has earlier sinned?" 
Paula is bored with life, but she is human enough to long for love and sympathy. She does not sean to be able to shake off the ideals and habits of her earlier life, and for this reason, she cannot gain happiness and respect. She is described in the first act:

"To do her justice, she is a type of a class which is immoral. Physically, by a strange caprice of creation, curiously beautiful. Yentally she lacks even the strength of deliberate vioiousness. Her affections, motions, impulses, her very existence a burlesque."

Paula sees the hopelessness of her position and realizes that when her physical beauty is gone, her ability to attract will also vanish.

"You'11 see me then at last with other people's eyes--youlli see me as your daughter sees me, as all wholesome folk see women life me. And I shall have no weapon to fight with, not one serviceable little bit of prettiness left me to defend myself with A worn out creature broken up very likely some time before I ought to be---my hair bright, my oyes dull, my body too thin or too stout, my cheeks raddled or ruddled---a ghost, a wreck, a caricature, a candle that gutters, call such an end what you like."

She prefers death at her own hands to an end like the one she has pictured.

In The Motorious Irs. Ibobsmith, Agnes is wayward through strength, not through weakness. She is a strong believer in free love, and is shown the folly of her theory. 
In Wilde's Iady Windermere's Fan, Hrs. Brlynne is the type of adrenturess redeemed. In 1 Woman of Ho Importance, we find portrayed a character more sinned against than sinning--Urs. Arbuthnot. Another example, less immoral than the others, is that of Irs. Cheverley in The Ideal Husband. and in salome wo find the leading figure the personification of revolting lust. She is wayward through passion alone. There is no redeemable reason for her wickedness; nothing to incite our pity or our admiration.

Quite another form of "past", which is by no means an immoral one, is brought out in Jerome $\mathrm{K}$. Herame's pleasing little play, The Hew Lady Bantook, or as it is sometimes called, Lanny and the Servart Problem. Here we have Fanny married to a lord whom the has been led to believe a poor artist with a future. When she is brought to his home is is amazed to find her own aunts and uncles and cousins serving as maids and butlers and footmen to the lordis family. This, wbother with the fact that she was a daneing hall girls forms her "past". Naturally the situations are musing, and an excellent play has been woren from a past that is out of the ordinary though having no taint or stain of immorality upon it. The only moral which we can find in this drama, if it might be called moral at all, is that no matter how hard we may try to keop a secret, it is bound to come out sooner or later.

In Clyde Fitch's The Truth, we have a phase of the wayward woman in a lighter sense of the word. There are no lives at stake 
but the results are almost as disastrous. Becky warder has one great sin---the sin of telling little white lies, when the truth would be much easier and the consequences less dangerous. Great lies from little lies grow, and Becky finds that she is not able to tell anything except 1ies. Fitch does not iwsh to make this play a tragedy, so he has Becky brought to her senses and the play ends happily.

"If I cantwin back his love the truth, I'II never be able to keep it, so what 's the use of getting it back at all?" Warder sounds the keynote of the play in the last few lines:

"Te dont love people beacuse they are perfect--we love them because they are themselves." The interest in this play lies not in the study of fashionable sooiety, but more in the portrayal of human nature, particularly that human nature of which Beoky is the exponent.

In sumining up these wayward characters, Uonna Vanna, taura Murdock, Audria, Paula, Mrs. Fbbsmith, Mrs. Frlynne, Mrs. Arbuthnot, Mrs. Cheverley, Salome, and in the lighter sense of the term, Fanny and Beoky, it is interesting to note that vices are not pictured in glowing terms not colored in brilliant tones. Vice and licentiousness are not described in such a way as to corrupt the minds and morals or the readers. As a rule these women reap their punishment. The women who are wayward through malice or personel weakness either die or live lives of misery. The modern dramatist has treated the subject in various ways, but invariably double living, deceit and immorality are censored and the characters punished according to the sin. 
Chapter III.

THE ETERNAL TRIANGLE. 
Chapter 111.

THE ETERNAL TRIANGLE

Perhaps the main reason modern dramatists have used the eternal triangle so frequently in their plays, is that it is an easy way of getting the main characters into a tangle. Of all of the thirty-six dramatic situations which a certain Frenchaw, Poli, has estimated as the total number available to writers of plays, this triangular one is by far the most popular. It is not a distinctly modern idea. It has been used with variations for many years, and it is as common among romantic writers as with realistic ones.

Plays centering around the theme involving the honor, justice, love, hate, envy and revenge of three main chacacters are of two distinct types. These are the plays which envolve the struggle of two men for the love of one woman, usually the wife of one of them, and those which center around the struggle which comes as the result of two women's love for the husband of one of them. Naturally modern dramatists have found various solutions to the tangles, and it is therefore, not the idea with $\mathbf{n}$ which we are chiefly conoerned, but rather with the untagling of the matted threads, and the inevitable resulting punishment which comes at the end which interests us. 
The main reason for our interest is that there

is always a woman in the case. Whether she forms only one side of the triangle or two sides, in most instances she is more definitely and distinotly drawn than the male character.

It is interesting, too, to notice that many dramatists in projeoting an eternal triangular theme, have used art as a background. In disnnunzio's The Doad City, we find the leading man, a poet. He is married to Anna, loveable, self-sacrifioing blind girl. Inna realizes that she can never give to her temperamental husband that which his poetical nature orares and demands. She is far from boing morose and selfish, for when sho discovers that her husband is falling under the spell of Bianoa Karie, she wishes him to marry hor. Her altruism carries her to plan self-destruation, and his happiness and his success in the artistic world are all that she holds uppermost in her heart. Her tragic ond is arerted by the death of Bianca, which while settling Annais mind, leares the poet bereft of his inspiration. It is left for the readers to decide whether or not he will ever reach to the heights of genius that he would have gained had Bianca Marie remained to inspire him.

To dinnunzio art is more vital than 1ife. Conventions are as nothing to hik. To Ibsen's way of thinking as illustrated in Then We Dead Arrake just the reverse is tbue. Ibsen, it must be remembered, is more deeply interested in life problems and the 
reaction of personality and human nature against circunstances and conventions. For this reason in accordance with his creed, art is secondary to nature.

In the case of When To Doad Arrake, the man is a sculptor. He is torn between love for his wife and love for his model. To Rubek, the man, art is supreme, it comes above love, above everything. He suppresses his love for his model and uses her merely as an inspiration for his work. He refuses to see that he might have combined love and work and succeoded in getting a perfect working harmony. Ibsen has shown us that "in failing to remain true to his impulse to love he has lost his power of further creation". His work, we are told, is not up to standard, it is commonplace, a farce, petty and crude in comparison with his former achievements. To get away from himself he marries another women whom he does not love. Later on he meets buteisst model and learns the awful truth that he has smothered out "the self" he loved in her. She is by no means the same, she is but a shell of her former self groping about in the darkness with no sense of direction. Rubek believes that he can awaken himself and Ironec

Therefore, without taking into consideration the wishes of his legal wife, he leaves her, and he and Irene climb the heights together. They are supremely happy, for they have found each other and are reawakening together. In the height of their so-called happiness they are buried by an avalanche. 
Yaia, the wife, is glad to be free from her husband, and far down the cliff she is rejoieing in the love of a wild bear hunter, whom she has found to be a more suitable mate. Death reunited Rubek and Irene, and the frdedon gained by death was more precious than life had ever been. Ibsen and dinnunzio in Then Te Dead Arrake, and The Doad City have taken up the oternal triangle as interpreted in terms of romantio variations. DAAnnunzio in La Giooonda has touched a littlo on the reallstic. While the play is still romantio in spirit, there are parts which border precoptibly on truth.

The world mast be tragic indeed to the wife who cannot supply the inspiration which is necessary for the husband's display of genius and artistry. The degree of tragedy is determined by the personality of the wife in the case and by the attitude with which she meots the situation. Wo sew the pathos of the situation when the wife realized, in The Dead City, that another woman was filling the place that was rightfully hers. In Ie Gioconda wo find a similar situation worked out by women of entirely different temperament. Lucio is a successful scupptor. He is extremely weak, and he realizes fully that Gloconda is creeping into his heart eaoh time she enters his studio. He has attempted to commit suicide before the curtain rises on the first act, beacuse of his despondency over his relations with the two women. He owes his physical health and his Iife to his wife, but he owes the life of his art to fioconda, his mistress, who has visited his studio daily during his illness and 
placed damp elothes on the clay which forms the unfinished statue. Sylvia, the wife, is necessary to Iucio's physical life; Gioconda to his artistio life. Briefly the story is this: Wile Lucio is convalesing, a message is brought to him from Gioconda stating that at a certain hour each day she will be waiting in the studio for him. Sylvia learns this, and realizing that her woak husband cannot withatand the lure of a moman of Giocondats type, determines to go to the studio and order her to leave.

The two women meet on common ground. Gioconda does not readinize sylviais authority to turn her out of the studio, and refuses to leave unless dismissed by Lucio himself. Sylvia, realinzing that Luoio will never exert onough will power to do such a thing, resorts to a lie to preserve him for herself and to rid him of the vampire's clutches. She tells Gioconda that it was Iucio who sent her to tell Gioconde that he will never see her. Gioconda forthwith becomes a fiend, a mad woman, intent only on her evil and malicious purpose. She darts swiftly behind the screen which shields the preoious statue, and is bent upon destroying it. Hithertofore, Sylvia has played only a small part in the artistic life of the young sculptor, but when put to the test she discards all personal fears and physicel charms and stretohes out her exquisite hands to catch the statue as it falls. Iucio enters the studio as the statue crashes, crushing her hands with the force of the impact. Sylvia knows that he has cone in response to the lure of Gioconda; she realizes that her sacrifice has been in vain. 
The last act of the play is more tragic than the climax. In it we find the maimed sylvia in conversation with a strange fairy-like beggar maid. She is telling the girl that she gave her hands for her 10ve. It is apparant, however, that she is convinced her sacriflce was too great a price to pay; her husband has left her.

D'Annunzio exouses the weak Lucio on the grfounds that he is an artist. Ibsen would not have been so lenient. He would have made him responsible to the code of manhood and to his nature as a human being no matter how temperamental he might be, rather than to his ambitions as an artist. DiAnnunzio says he is duty bound to follow his inspiration, but this serves only to make him weaker morally and spiritually when measured by our present-day standards. Iucio knows but one law, that of his own making. His work in the world is to create statues, and when a material form has gone out of his hands with the imprint of beauty upon it, he states that "the office assigned to me by nature is fulfilled". The weakness of Lucio, however, serves only to emphasize the strength of sylvia. He was too blind and unprincipled to realize that her strong love, her beautiful and righteous soul, her winning personality---all of these qualities----could have afforded him the inspiration he needed for his work.

Sylvia is entirely too good for her husband. She forgives his unfaithfulness and hopes to win back his love by her infinite faith in him, just as she has won back his health by her loving care. 
She is pleased and happy when Iucio pledges afresh his individual affection for her. But he is too weak to live up to his promise. Gioconda hes too strong a hold on him for him to release himself merely by willing to do so. Sylvia, on the other hand, is not the type of woman to give up her possessions without a struggle. She is no blind Anna in a dead city. She is alive to the seriousness of the situation, and she intends to fight for what is hers with every bit of womanly love and stratedy within her. All of her soul is in the qocusations she brings against the unprincipled temptress. There is force and conviction in the words:-

"Tell here is a woman who has drawn a man into her net with the utmost allurements; who has torn him away from the peace of home. the nobility of art, the beauty of a dream which he has nourished for years with the flowers of his force; who has dragged him into a turbid and violent delerium where he has lost all sense of goodness and justioe."

Naturally Gioconda is prepared for this, and she gives her viewpoint in the following lines:-

"The woman against whom you made such accusations was ardently loved, and suffer me to say its2with a glorious love. She did not abase but exalt a strong life."

Gioconda's chief fault was in loving another man's husband. She does not feel a sqnse of guilt at bringing unhappiness upon sylvia. In fact, she explains that sylvia's dilemma is of her own making.

"All your hands, all, above all your hands of goodness and pardon, prepared for him every night a bed of thorn, on which he could not ile down. But when he entered here, I awaited his as one awaits the creating god, he was transformed. Before hsid work he recovered strength, joy, faith."

Gioconda is not vulgar but she is unprincipled. She too, like Iucio, knows only one law--one rule of conduct and that law she has created to suit her own wilful and immoral purposes. While she 
is undeniably Lucio's istress, she thinks less of his person than she does of his art. Her laws of oonduct she has made to govern in the realm of art. In speaking of his studio, she shows her moral code:-

"Yhis is a place outside laws and beyond common rights. Here a sculptor makes his statues....... Nature has sent me here to bring him a message, and to serve him. I obey."

DiAnnunzio places the artist outside the pale of conventional morality. The artist must be inspired by love, but that love need not necessarily come from his wife.

$* * * * * * * * *$

In Yaeterlinck's Pelleas and Melisande the plot is reversed, for here we have two men in love with the wife of one of them. The story mus like this, Goloud and Pelleas are half brothers. Conloud is old and a widower. Pelleas is young, handsome and care-free. one day Goloud while riding in the wood loses his way and comes upon Melisandre sitting by a spring in the forest. She too, is lost. She is a queer, half frightened creature of great beauty, and is afraid to have Goloud touch her. After some time she agrees to accompany him home preferring as the lesser of two evils, perhaps, marriage with the kindly man rather than to suffer from the dangers of the dark forest.

Goloud at length brings her to his palace where he introm duoes her to his handsome half-brother. Pelleas goes forth to meet Melisandre and falls desperately in love with her. It is the old call of youth to youth.

sct II, is set by a fountain in the park. Melisandre and her lover are watching the sparkling waters in Blind Man's Spring. 
Melisandre is toying with the ring her husband gave her, when it slips from her hand and falls to the bottom of the crystal spring. At the same time Goloud is thrown from his horse and is injured. Melisandre, while nurshing him, begs him to take her away from the place. She seems to fear her own heart. She has a premonition that she will never be happy under the existing conditions with Pelleas in the house. Goloud, on the other hand, thinks this is just a foolish idea and pays little attention to it. He does notice, however, that she is not wearing the wedding ring. He is much upset and demands that she go at onee and search for it. Melisandre cannot go alone at that hour of the night, and Goloud insists that she take Pelleas with her.

Goloud's suspicions are increased when at midnight he comes upon Pelleas bathing himself in Melisandre's flowing hair, which she is combing by her bedroom window, Treating the incident as the act of playful children, he realizes that something more than child's play is being enacted before his eyes in the moonlight.

"You are children, Malisandre do not lean so far out the window, you will fall. Do you know how late it is? It is nearly midnight. Do not play so in the darkness."

In order to gain further proof to substantiate his suspioions of his wife's infedelity, he questions his little son, Inivol. One of the most intense scenes in the play in Act IV, scene IV, where Goloud holds his son up to Melisandre's window to have him spy upon the lovers and report what he sees to him. What takes place is more ofiggented than related, but the scene is more powerful for the mission of details which we feel are inclusive. 
Pelleas decides to go awry, but first he must tell his love good-bye. They plan a meeting at the fountain where previously they had their secret meetings. Before her arrival at the scene of parting, Pelleas soldldquizes:-

"It is the last evening---it must all end. I have played like a child about a thing I did not guess. I have played a-dream about the snares of fate."

Melisandre comes to meet him. They declare their mutual love for each other and meditate on the fact that their state of bliss cannot last more than a moment or two. As the two embrace, Melisandre grows aware of the presence of her husband and knowing his nature realizes that nothing will prevent him from exerting violence in his anger and jealousy. Goloud comes upon the,. He strikes at Pelleas, hurls him dead into the spring, and then pursues his wife into the forest.

The end, like that of La Gioconda is more tragic then the story. Melisandre lies dying, not of the wound she has received at the hands of her infuriated hushand, but from a broken heart. She protests her innocence to Goloud on her. death bed, but stoutly affirms her love for Pelleas.

Melisandre never loved her husband., and when the ory of youth and romance came to her, she felt no pangs of conscience at falling in love with Pelleas. The play itself is artificial both in setting and in the choppy episodes of love and jealousy which form the scenes. The characters are not flesh and blood creatures but fascinating models from the imagination of a romantic dramatist. The only real episode is the tragedy which results from the conflict of the three main charqcters. 
Maeterlinck has written another play similar in theme to that of Pelleas and Yelisandre. In this case, there are two women involved in the triangle. Ordinarily there is an intense hatred existing botween the two sides of the triangle. In La Gioconda the hatred bordered on the fiendish. The striking difference between Maeterlinck's Aglarane and selysette and the other plays of similar theme 1 iee in the fact that there is a mutual affection between the two women rivals.

Selysette is a quiet gentle woman who would rather be loved for herself alone than to do her part towards keeping the affections of her husband. She makes it a point to conceal her strongest feelings whenever she is with her husband, and he mistakes this undemonstrativeness for coldness. She admits that when she is in her husband's presence she represses all her emotions.

"I do not want him to lore me beacuse I agree with him, or beacuse I can enswer him. It is as if I were jealous of myself." In other words, Selysette takes all and gives nothing. In strong contrast to the wife, is the emotional expressive Aglavine. It is to her that yeleander goes to seek the comfort and understanding that his wife cannot, or will not, give him. Naturally selysette is shoeked. She is human enough for that. But she is nit strong enough to go out of her natural path to regain the love she has oast aside. She is no Sylvia. When she recovers from the disappointment and pain, she conceives for Aglavine an ardent love. Perhaps the most unnatural and abnormal part of the play is the affectionate regard which each woman holds for the other. Neither is it natural for Aglavine to 
discuss oalmly the state of affairs existing:-

"I love you, I love Meleander; Yealeander loves us both. You love Keleander and myself and for all that cannot live happily together because the hour has not yet come when mankind can thus be united."

Meleandw is a strange creation. At first he cannot understand his quiet wife, and he seeks companionship in the society of the toher woman. Then as the play progresses, he learns to a ppreciate his wife. Aglavine points out the solution to the plot, and Sylsette, silly little sentementalist that she is, decides to follow. Aglavine tells sylsette that "either one of us must die, or the other must go away". By the other, she most probably means herself, but wo do not see her making any preparations for departure. Sylsette arranges to commit suicide. She falls, as if by accident, from the top of a ruined light house and leaves her husband and her rival to live happily ever afterward.

Yonna vanna is another example of the eternal txiangle. Here Prinzivalli is drawn to one corner of the figure by the force of a husband's suspicions to bind a wife to the man suspected. Guido makes the triangle a tangle of barbed wire of suspicion and treachery by his inability to believe the truth as it is ppoken.

There are few happy endings to the dramas which have for their theme the triangle. Someone must pay for the folly of others. In The Dead City Bianca Marie dies in time to save the wife from suicide. In When We Dead Arake, Rubek deserts his wife whi is relieved to be left alone. In La Gioconda the wife suffers the loss of her hands after a struggle for Lucio's love. In Pelleas and Melisandre, Melisandre dies and Pelleas is killed by the infuraited husband. In Aglavane and selysette, the wife gives up her life in order that her husband may be free to marry 
her rival. The doctor dies in The Doctor's Dilemma and in Ionely

Lives, Dr. Johann Vockerat takes his own life rather than be separated from his soul mate.

Taking it all in 211 , the dramatists of to-day seem to consider it dangerous business - - this dealing with triangles whose cornders are men and women imbued with the natural longings, passions desires and eravings which govern our conduct as human beings. 
Chapter IV.

WOMEN AND COMMERICALISH. 


\section{Chapter IV.}

\section{WOMEN AND COMMERCIALISM}

Woman has risen step by step to a position of world-wide reoognition. Just as she has adxanoed from the humdrum existence of the conventional family circule along the paths of waywardness, at times, to a higher plane of usefulness in life, just so have the modern dramatists portrayed her on the stage. The time has long since past when women sat in the background and let the men hold the center stage and received all the applause from the audience. The spot light of interest is certainly concentrated to-day upon woman. True enough it may as often be a light of condemation and recognition of her faults as well as of her virtues, but no matter what it is, it is a light of appreciation of her position.

When woman stepped out of the home, she invariably sought to do some kind of work which would put her on an equal footing at least financially with her husband and brothers. The time too has passed when a woman in business is a woman scorned. Of course there is no necessity of woman's going outside the home. to be effective in commercial circles. The influence which she can exert in the world of business may come by her personal assistance to her husband directed 
The family life in many instances has been seriousIy affected by commercialism, and women have aided or suffered, as the case might be, as a result of the excessive attention of the men to business affairs. The most interesting group in this connection is that in which the family life is acted upon by some form of commercialism. The problem has been treated in various ways; satirically by some, seriously by others. In A Bankrupt by Bjornson, Tjalde is, to all outward appearances, a prosperous man. This seeming prosperity has come at the cost of neglect of wife and family. In reality he is losing money. He justifies his attempt to keep up appearances by declaring it is the only way he can save the confidence of his people and the sums confined to him by others. Suppicion is cast upon him, however, and an agent is sent by the bankers of Christiana to inspect his accounts.

The end is inevitable. He makes one last grand effort to divert the suspicions by entertaining in elaborate style for a visiting magnate. Then the agent soes him in his true light, he begs him to throw off the cloak of deceit and start anew. Instead of the bloody ending which would have resulted had not the agent been calm and composed when Tjalde threatens to shoot either himself or the agent, there is a happy one in which the wife and the daughters give up their struggle to appear prosperous. The family ties strengthen. To add an unusual turn to the plot, and change the tide of affairs, the agent returns to 
clain the daughter for his wife. There is in the play a decided stress laid upon the evils of living beyond ones means, of pretending to be that which one is not. There is a marked contrast between the haggard misery existing in the family when they struggle to keep up appearances and the happiness of a life of simplicity.

A family affected by the lust of money forms the basis for the play by Ootave Mirabeau, Les Affaires sont Ies Affaires, or Business is Business. It is the story of a man who stops at nothing in his mad desire to make money. To Lechat gold is a god and efficiency is a deml-god. Everything he touches turns as if by magic to gold. He is unusually successful in everything he undertakes but his success comes at the price of his friends and family. To him everything has its price. His motto is "I never buy, I always exchange". His wife is a miserable woman who fares not call her soul her own. His son takes to betting and is killed in an automobile accident, while his daughter marries a man far boneath her in the social scale. Ioohat thinks his daughter's suitor has brought up a plan to make money, and he asks him what his price will be. Everything, you se0, has a price to him. It is startling news when he finds that such is not the case. It is distinctly a materialistic world in which he lives; a world of gold-giving only to accomplish gold-gotting.

In Sowerby's Rutherford and Son the blight of commercialism falls upon the family through derotion to business by the head of the family. 
Henri Becque has added his contribution to commercial drama by The Ravens. It deals with the fate of lme. Vigneron and her children. After the death of her husband, she must witness the coldapse of the family fortunes and the preying upon her of the ones who professed to be her best friends. Each daughter, trying vainly to replentish the family fortunes, finds only heartbreaks at the end. Blanch is deserted by her lover; Judith, who previously had been encouraged to make a name for herself in musio, is scorned by her professor when she tells him she wishes to aid her family materially. Yarie is offered marriage by an old man whose money is the only remaining means of recuperating the family effects.

In all of the abovo-mentioned plays, the women have suffered to a great extent from the sins of the men whose hearts and souls are wrapped up in the desire to make money. Commercialism has ehtered the heme and left a lasting mark on the peace and happiness of domestic life.

Granville Barker has cleverly interwoven the threads of family life love and morality with a background of commeridisism into a satirical comedy. First of all, it is evident that Barker as a writer of intelleotual dramas is not content with making mere family studies in the naturalistic fashion. His family groups are not backgrounds fort home problems, they have well-defined purposes, which are vastly more important than character portrayal.

Two branches of a rather curious family are depicted in 
The Yadras House, the Huxtables and the Madrases, products of the drapery trade. A philosophic promoter proposes to unite with others, the houses of old $\mathrm{Mr}$. Fuxtable and Constantine Madras, brothers-in-law and business rivals who have not spoken to each other for many years. The satire on trade and trade conditions in relation to the family 1 ife is what interests us most acutely. The Huxtable family is made up of daughters, a conventional mother and father throw in, as it were, for good measure. The six girls are all unmarried, for various reasons, and have been falsly restricted from the society of men. Laura seeks solace in housekeeping; Hinnie and Clara find little relief in missionary work; while Emma, who has a natural bent for business, is foroed to remain idle besause a woman in her position should never be "in trade". It just isn't considered proper 1 Jane, the youngest is not allowed to marry, and has had to refuse her two proposals because her acceptance wbuld lessen her sister's chances of securihg suitable husbands.

The Madras branch of the family consists of constantine Madras and his wife, a son and a daughter-in-law. Constantine $h_{\mathrm{a}}$ s gone to Arabia to practice his queer theories in regard to women. He regards Buropean men as softened, sentimental and rotted by being lapped in the "cotton wool of prettiness and pettiness", and he upholds the Yohammaden view of women because he believes it ot be franker and more manly.

Philip carries on the business in Constantines absence. He negleots his wife, but after neglecting her for a certain length of time realizes that he is pursuing the wrong trade and gives up his 
business position for politios. His aim is to "terch Humanity to come of age".

The emancipated view of women is expressed by Miss

Yates, one of the Huxtable saleswomen. Implicated in a serious scandal, she does not feel ashamed or degraded by her folly. In her attitude toward her orm immorality, she stands out in marked contrast to Phillip who declares that he is unconventional but that he does not do unconventional things.

An interesting phase of the policy of the Huxtable business is brought out in the fact that they believe the worls is regarded as a conspiracy of buyers and sellers who make the most of bargaining with each other. A plan is adopted whereby each salesman is given a chance of wait upon the women customers, and the saleswomen upon the men buyers. At the Madras house Constantine attends a private display of gowns freshly imported from Paris and worn by pretty models who are put through their paces by a tailor made man-milliner with an affected walk. The psychology which Barker wishes to bring out here, so it seems to me, is that women respond more readily to men and men more readily to women than they do to members of their own sex.

An entirely different view of the effect of women on the comercial and professional career of a man is brought out in one of Barrie's most amusing and pleasing plays, What Every Woman Inowe. The drama is delightful in the presentation of a slice out of the lives of two very important characters, Maggie and John Shand. 
With true Barrie unusualness the play opens with Maggie's father and brothers preparing to wit up for a nightly intruder. We are prepared for the appearance of laggie by the conversation which takes place before her arrival. From it wo loarn that she is twenty-five, unattractive and unmarried. It is just like Barrie to add to her make up a delicious sense of humor which counteracts all her shortcomings and gives her a distinct charm.

The intruder proves to be a certain John Shand who has forcod his way almost nightly into the house of his neighbpr in order to read from his well-stocked library. John is twenty-one, good looking, and also unmarried. He is struggling along trying -.. to work his way through law school.

A bargain is made. A bargain such as only Barrie could have conceived. John is to marry vaggie at the end of five years, is she wants him, in return for the loan of a certain sum of money sufficient to pay his way through college. The brothers tell John that there is little doubt but that Maggie will have married in the meantime, since she is much sought after by many suitors. Kaggio shows her true colors at the start. If she is to be included in her brothers rediculous bargain, John shand is to - know at the beginning all the conditions and the possibilities. $S_{\text {he }}$ intends that he shall accept their proposition with his eyes open. And to bear out her determination to be fair, she tells him 
that she is utterly without oharm, at least the charm which attracts eligible young wen for husbands. The oompact is signed.

six years pass. John's great hour has come. He is running for Parliament and the election night is at hand. He stands for civ1l and religious freedom, faith and hope. As Barrie puts it, "It is snowing Shand in Glasgow". The brothers express their doubt by saying he was made to think he could win out; that it is an insane ambition that made him seek the office. Maggie alone believes that it was a glorious ambition that made him run the race. Only Yaggie, then, who it is plain to see, is deeply in love with shand, but who refused to marry him until the fate of the election is known, stands by urging him on and protesting that it was a wonderful thing for him to try to win out. The faith in her lover is clearly brought out in the words she utters (half to herself) before John comes to tell of his defeat or his victory. All is excitement. "Did you say you had lost, John? Of course you would lose the first time dear John. Six years? Very well, weill begin another six to-night. Never give in, John, never give in." Maggie's words of reassurance and encouragement are not needed, for before her words are hardly out of her mouth, the room swims with the thronging peoplel Joh has been elected M.P. He, blind egotist that he is, tells Maggie, "I've done it Yaggie, and not a sould can help me. I've done it alone." He is now ready to fulfill hisppart of the contract, although he makes it clear that there is no emotion akin to love 
to stimulate this bond of matrimony. He is marrying her simply to carry out his part of the contract. Kaggie is willing to release him from his promise saying, "A woman never rises with a man, John. I'll drag you down." John insisting that it is his honest duty to marry her, intends to go through with his part of the bargain, but again she pleads, "You'll miss the pretty iest thing in the world, John, and all owing to me. Romance." Surely Lggie knows what she is talking about, for she is experiencing the same sensation which she knows will some day come to John. She is feeling the exquisite thrill of being in love, honestly and wholeheartedly, with the newly elected M.P.

"Allis cold and gray without it, John. They that have it have slipped in and out of heaven." She is still willing to give him the chance of breaking the bonds which bind John to her side, but John, honest with all his egotism, refuses to let her. When Maggie sees that he is bent on marying her, she almost shrieks, "I'm essential to your career, and you're blind not to see it." "In no cirounstance would I allow any meddling with my careor." shouts back the egotist. And so they are married.

John accepts Kaggie as one would accept a piece of ordinary property of little value which has been left him in some foolish will. He respects her, but there has never been even the smallest spark of love in his heart for the woman who is his guiding light. Maggie, with her foresight, her humor, and her understanding of human nature, sees that her contractehusband is slowly but surely 
falling in love with Lady sibyl, a frequent visitor at their home. Is she infuriated at this unexpeoted development in their domestic affairs? Does she storm or woep or wail at her husband for his weakness? Iot at all. She has promised John that she will not be like other wires, so her next action is not altogether unexpected. She arranges for John to leave her and plens to have him spend several woeks with an old friend of his in some out of the way epot in the country. She also arranges to have her rival invited to the same house for the same length of time, lmowing with her rare wisdom and common sense, that if John really loves this intruder, he will have his love strengthened by the wooks spent together. If, on the other hand, he finds that what he thought to be a grand passion is only a fleeting fancy, her constant companionship will cure him of his infatuation.

In the country John is hard at work on what he hopes to be the most brilliant ppeech of his oareer. Something, however, is certainly missing. Perhaps it is the presence of Maggie with her knitting, at his desk beside him, whose clever suggestions have always seemed to work themselves into his speeches. At length the speech is finished, but even John feels that it is not up to his usual standard. It proves a flat failure.

Upon the scene appears Maggie with the notes of his original manuscript neatly typed with her suggestions interwoven to make a perfect whole. Undoubtedly it is John's speech, but decidedly different from the one he has written with Lady Sibyl at his side. 
This speech is as complete as success as the former one was

a failure. At length the truth begins to dawn upon the stupid M.P., and he condescendingly says,

"By Gosh, Maggie, you're no fool." Barrie tells us that Maggie beams as any wife would. There is a period of quiet reigning. Finally the silence is broken by John over whom the dawn of understanding is just beginning to break. "Maggie, what if it was you that put those queer ideas into my head?" Maggie replies, "Is it too terrible to find that my love for you has made me able to help you in rittle things? It is nothing unusual that I have done John; every man who is high up loves to think that he has done it all himself and the wife smiles and lets it go at that. It's out little joke, every woman knows that".

The play ends with John attempting to bring to light the wee little smile so much desired by Maggie. It is a great event when it finally does arrive.

It took a long time, and it was a tedious lesson for John to learn that his wife had been the source of his inspiration all the time. It is the age old truth brought to light in a fascinating little play that we do not appreciate the things we possess until those things are snatched from us. Barrie might easily have made his play into a tragedy by having Maggie scorn her husband who has tired of her. just when he finds that she is essential to this career; the pivot around which his genius revolves. But this is not Barrie's 
way. He endowed his heroine with a sense of humor, and surely bhe needed it as the wife of a man who boasts that he never laughed. Woman's is surely man's funny bone. In order'to make them all live happily ever after, Barrie has Lady sibyl tire of John, find her a bore, and hand him back unharmed to his lawful wife.

In What Every Woman Knows, there is a problem of the home, a queerly constructed triangle, and woman's position in the prom fessionaluaffairs of her husband definitely and interestingly worked out. There is a clever demonstration of the conceit of man and his awakening to his wife's part in his professional success. Woman, then, no longer draws her skirts away from the tide of comercial affairs. She is vitally concerned with them, and although she does not necessarily have to take an active part in the making of the family fame and fortune, she is nevertheless implicated in the results of her husband's or father's desire to become professionally successful or rich. Her husbands affairs are her own affairs. 


\section{COMCLUSION}




\section{convelostor}

What now, in conclusion, has been the aim and soope of this thesis? What have we accomplished after all in this dissertation? Thy have we attempted to analyze plays and point out peculiar characteristics of certain characters?

Drama has ever been an important factor in the representation of life and life problems and in the possible soultion of them. Woman has been a vital element in these momentious problems. Women and drams then may bo appropriately classed together and considered in relation to each other. It has been my aim, then, to debermine what has been woman's effect on drama, and how the drama has been adapted to bring out the personality and nature of the woman charactors.

We saw women, first in the home, exercising some little power, or playing some great havoc with the destines of the family of which she is an integrel part. We have attempted to whow Ibsen's conception of married life and his solutions of the woman problem in the three of his best-known plays. For illustration and study we selected A Doll's House, Hedda Gabler, Ghosts, and Anspacher's The Unchastened Womar.

We could not give a broad view of the part which woman has played in the modern drame by slipping lightly over the evils 
to which she is heir. The very fact that dramatists have considered woman wayward both in past in and present, is a step in the direction of public acknowledgment of woman's place. The very fact that the dramatists consider her sould worth worrying about, and of equal importance with the salvation and problems of men, shows that they admit that woman is necessarily a human element to be reckoned with in conventional society.

Yonna Vanna, The Easiest Tay, Michele and Eis Lost Angel, The Second Mrs. Tanqueray, The Notoriaus Mrs. Ebbsmith, Lady Windermer's Fan, A Woman of No Importance, The Ideal Husband, The New Lady Bantock, and The Truth, all bring out in the dramatist's own intividual way the conception of the wayward woman.

Woman have affected in a great messure, the destines of the home. From the interference of another woman in the domestic Iife of a married couple, or the interference of amn or woman in the social and moral environment of two other people, there has grown up what modern dramatists choose to call the othernal triangle. This triangle with human beings at the corners, has played an important part in the weaving of themes for the modern dramas. D' Annunzio's La Hiaconda, Maetherlinck's Pelleas and Melisandre, Monna Vanna, Aglavane and Selysette, Hauptman's Lonely Lives, Shaw's The Doctor's $D_{\text {ilemma }}$ are excellent examples of various phases of the triangle.

Perhaps the most modern theme used in recent drama is that which shows the effect of commercialism on the modern family life 
and more especially how women characters have been effected by it. Woman has shown in real life that she is capable of taking her rightful place in the world ofhbusiness. The modern dramatist, realizing that the emanoipation of women is an assured fact, has played upon the theme in many interesting plays. The ones which we seleoted for spweial disoussion are Bjornson's, A Bankrupt, Dctave Mirabeau's Ies Affaires sont Les Affaires, Henri Becque 's The Ravens, Granville Barker's The Madras House, and Sir James M. Barrie's What Erery Woman Knows.

In the last chapter we have taken up a new phase of woman's activities. Not as a wayward woman preying on the lust and the passions of an hour, wrecking the lives of those with whom she comes in contact, not as an intruder in the domestic happiness of a contented home life, but as the gog in the wheel of industry or as a vital element in the profession of husband or father.

It is a far cry from Nora Helmer to Maggie Shand. In A Doll's House, the first play discussed in this thesis, we found Nora, the petted doll wife of Helmer awakening to the artificiality of her existence in the house that has been erected for her by her well-meaning husband. In What Brory Woman knows, the last play to come to our consideration, Uaggie is the voman at the root of the professional success of her egotistical husband. From one extreme we have gone to the other in the space of five chapters. From home and family life we have taken you to the work-a-day world of business. We have attempted to bridge the gap with the presentation 
of various phases of woman themes and to show the reaction of women to the problems of the modern drama.

Iife would be a dull drab place without the women. If there be those who disagree, let them oall to mind a play, which after all is just a slive of life, in which there are only male characters. It is perfectly possible to weave an interesting play with only male characters on the stage. But it is extremely-doubtful if the interest of the audience would be sustained for long if only men and men problems are presented. Woman's place on the modern stage is not behind the back drop, nor in the bold conversation of the male characters. Neither is ner place in the theatre delegated to the dress circle where a dainty hand clap or an occasional titter behind a lace fan is the only evidence of her presence. Woman has worked hard for her position in the spot light; she belongs before the footlights with the flood of appreciation and recognition beaming warmly upon her raidant presence. Noman's place is an established onel 
PLAYS USED IN THESIS 
PLAYS USED IN THESIS

A Bankrupt...............................ns on

A Doll's House....................... Ibsen

Aeneid............................Virgil

Aglavane and selysette....................eterlinck

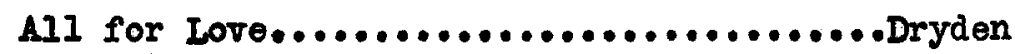

A Woman of to Importance................Wilde

Berde of Messina, The...........................

Business is Business.................... Mirabeau

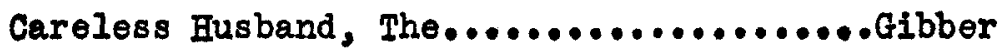

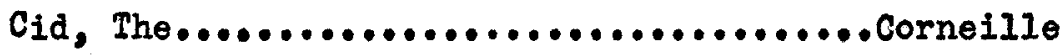

Clandestine Marriage, The....................eman and Garrick

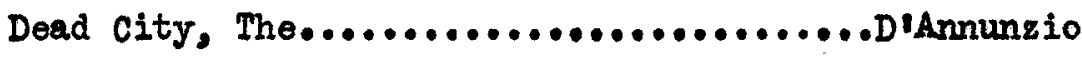

Doctor's Dilemma, The................ Shaw

Duke of Guise, The................... Dryden

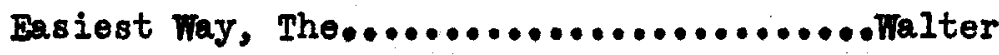

Fatal curiosity, The...................tillo

Faust........................ Goethe

Ghosts .........................Ibsen

Hedda Gabler,........................ Ibsen

Ideel Husband, The...................Wilde

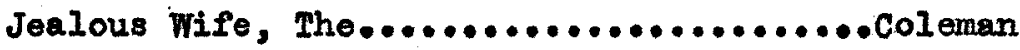


Lady Windermer $t_{8}$ Fan.................14lde

Le Menteur....................... Corneille

Les Plaideus......................Rgotne

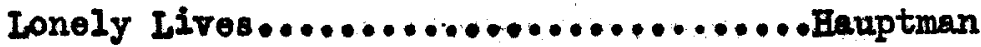

Yadras House, The,............................

Waha-Barata.....................epio

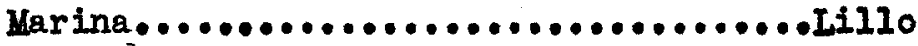

Sarianime...................Elardy

Michael and his Iost Angel.............Jones

Lonna Vanna.......................Laeterlinck

New Lady Bantock..Tho................Jerome

Iotorious $\mathbf{H s}$. Bbbsmith, The..........Pinero

Pelleas and Melisandre...............heterlinck

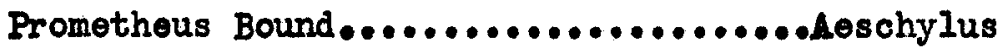

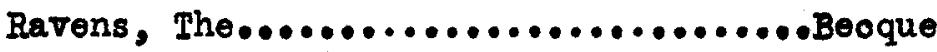

Rivals, The....................... sheridan

Rutherford and Son...........................

Salome........................ Filde

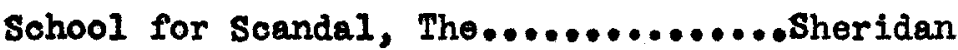

Second Urs. Tanqueray, The............Ptnero

She stoops to Conquer................toldsmith

Shakuntala.......................Kalidasa

Truth, The....................Fitch

Unchastened Woman..The............Anspacher 


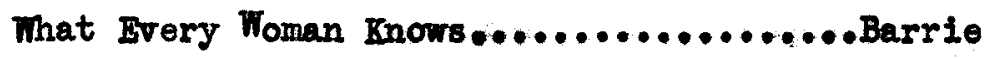

When Te Dead Arrake......................... Ibsen

Wild Gallant, Tho.............................

Wonder, The, A Wonian Keops a seoret.......urs. Cantlivre 
BIBLIOARAPHY 


\section{Fingall ormahertie, Plays of Oscar nilde, vol. 1-11.}

Howe, P. Dramatio Portraits, 4 . Konnody 1913.

Heller, Otto, Plays and Problems, Boston, Boughton Xiffin Co., 1918.

Huneker, James Gibbons, Zgotiots, 1 Book of Supermen, Charles scribner's Sons, 1909 .

Huneker, James Gibbons, Iconoclasts, a Book of Dramatiste; Charles Scribner's Sons, 1905.

Jameson, Storm, Modern Drame in Durope, $\pi$. Collins Sons and col 1905.

Boyesen, Hjalmar H., Goethe and Schiller, Their Ly res and Works, N.Y.,

Pinero, Sir Arthur Fing, The Hotorious Mrs. Ebbsmith.

Pierce, J. A., Masterpleces of Modern Drama; Doubleday Page and Co., Hew York, 1915.

Sheridan, R. B., The Rivals, with notes and introduotion by Joseph Quinoey Adams Jr., Boston, Eloughtonglifin to. 1910.

Hamilton, Clayton, The Theory of the Theatre, Henry Holt and Co., 1910.

Clark, Macdonald, Yaurice Maeterlinok, Poet and Philosopher, Fred 4. Stoker 1916.

Maeterlinok, Maurice, Aglavane and Selysetter Dodd Meade and Co., 1911.

Ibsen, Henrik, From Ibsen's Norkshop, Traanslated by A. G. Chater, Charles seriboner Sins, 1911.

Moses, Montrose J., Representative British Drama, Little Borwn and Co.

Pierce, John Alexander, Yasterpleces of Yodern Drama, Doubleday, Page

Eaton, Walter P., Plays and Players, stewart and Kidd Co., 1916.

Matthews, Brander, Chief Contemporary Dramatists, Houghton Miffin Co., 1916.

Dickinson, Thomas, H., Chief Contemporary Dramatists, Houghton Miffin Co., 1921.

Clark, Barrett H., The Conventional Drama of To-day, Henry Holt and Co., 1911. 
Hale, Edward E. Jr., Dramatists of To-day, Henry Holt and Co., 1911.

Henderson, Archibald, Buropean Dramatists, Stewart Kidd and Co., 1913.

Shang, Lewis C., Players and Plays of the Last Century, I.C. Page and Coo, Vol. II.

Burton, Richard, The Her Amorican Drama.

Loses, Lontrose J., The American Dramatists (Boston) Little Brown and co., 1911.

Ward, A. T. Naller, A. R., (edited by) The Cambrdidgeliastory of English Literature. Vol. VII, VIII, IX,XIV,XV, XVI, Cambridge, Ingland. University Press.

Bates, Alfred, The Drama, Its History, Literature and Influenoe on Civilization, Vols. VII?VIII, IX,IIV, XV, XVI. Cambridge, Ingland.

Towse, John Rankin, Sixty Years of the Theatre, Funk and Fagnalls Co., Now York and London, 1916.

Walloy, J. Fitegerald, Famous Plays, Ward and Downey, London, 1886

Goothe, Faust, Everyman's Library, (edited by Earnest Phys, parts 1 and 2.) E. P. Dutton and Co., Hew York.

Chandler, F. W. Aspects of Yodern Drama, Macmillan Cl., Hew York. 1920.

\section{Magazines.}

Review of Reviews, June 1911, v01. 43, pp.727-8

Sewanee Review, April 1911, vol. 19, pp 161-171.

Forum, Vol. 40, pp 265

Forum, vol. 41, pp213.

Atlantic Monthly, vol. 102 pp638. 